\title{
Estrogen enhances the proliferation and migration of ovarian cancer cells by activating transient receptor potential channel C3
}

Shengnan $\mathrm{Li}^{1 \dagger}$, Kuo Jiang ${ }^{2 \dagger}$, Jia Li ${ }^{1}$, Xiaohua Hao ${ }^{1}$, Wenguang $\mathrm{Chu}^{3}$, Ceng Luo ${ }^{3}$, Yuanyuan Zhu $^{3}$, Rougang $\mathrm{Xie}^{3^{*}}$ and Biliang Chen ${ }^{1 *}$ (D)

\begin{abstract}
Background: Recent studies have suggested that estrogen (E2) plays an important role in epithelial ovarian cancer (EOC). However, the mechanism of E2 in ovarian cancers is unclear. The purpose of this study was to investigate the effect of E2 on ovarian cancers and illuminate the mechanism of E2 in promote ovarian cancers proliferation.

Results: We demonstrated that E2 stimulated the proliferation and invasion of ovarian cancer cells. In this study, ovarian cancer specimens were also analyzed for transient receptor potential channel C3 (TRPC3) expression; TRPC3 expression levels were higher in ovarian cancer samples than in normal ovarian tissue samples. Previous studies have shown that TRPC3 contributes to the progression of human ovarian cancer. In this study, we further investigated the interaction between E2 and TRPC3. We found that E2 stimulation enhanced the expression of TRPC3 at both the mRNA and protein levels. E2 stimulation enhanced the influx of $\mathrm{Ca2}^{+}$. Moreover, siRNA-mediated silencing of TRPC3 expression inhibited the ability of E2 to stimulate the influx of $\mathrm{Ca2}^{+}$.

Conclusions: In conclusion, TRPC3 plays a significant role in the stimulatory activity of E2 and could be a therapeutic target for the treatment of EOC. Furthermore, this study elucidates the molecular mechanism by which E2 promotes the proliferation and migration of EOC cells.
\end{abstract}

Keywords: Epithelial ovarian cancer, Estrogen, Transient receptor potential channel C3 (TRPC3), Cell proliferation,cell migraiton

\section{Introduction}

Epithelial ovarian cancer (EOC) is the most common type of gynecological cancer. Annually, 230,000 women worldwide will be diagnosed with EOC, and 150,000 will die [1]. EOC represents the seventh most commonly diagnosed cancer among women globally and has a 46\% 5year survival rate after diagnosis. One of the main factors contributing to the high death-to-incidence ratio is the advanced stage of disease at the time of diagnosis

\footnotetext{
* Correspondence: rgxie@fmmu.edu.cn; cblxjh@fmmu.edu.cn

†Shengnan Li and Kuo Jiang contributed equally to this work.

${ }^{3}$ Department of neurobiology, Air Force Medical University, Xi'an 710032,

Shannxi, China

${ }^{1}$ Department of Gynecology and Obstetrics, Xijing Hospital, Air Force Medical University, Xi'an 710032, Shannxi, China

Full list of author information is available at the end of the article
}

[2]. The cause of this disease is not clear. Epidemiological investigation has shown that EOC is influenced by hormones, reproduction, genetics, inflammation, life habits and so on. The main treatments include surgery and systemic therapy [3-5]. However, the pathogenesis of EOC remains unclear. To date, numerous hypotheses have been proposed to explain the etiology of ovarian cancer [6-8]. Thus, new insights into the cause of EOC are urgently needed.

The ovaries are the main source of female reproductive steroid hormones. Several lines of evidence support the view that the growth of many ovarian cancers is regulated by estrogen $(E 2,[9,10])$. Moreover, E2 is one of the most important hormones in the female reproductive system and is mainly secreted by the ovaries. It

(c) The Author(s). 2020 Open Access This article is distributed under the terms of the Creative Commons Attribution 4.0 International License (http://creativecommons.org/licenses/by/4.0/), which permits unrestricted use, distribution, and 
exhibits a broad spectrum of physiological functions ranging from regulation of the menstrual cycle and reproduction to modulation of bone density, brain function, and cholesterol mobilization [11-13]. Both of the major isoforms of estrogen receptor (ER), ERalpha and ER-beta, are expressed in ovarian cancers [14]. However, the mechanism involving ER in ovarian cancers is unclear.

$\mathrm{Ca}^{2+}$ is a second messenger that plays a major role in the regulation of cellular functions such as secretion, cell growth and death, and contraction $[15,16]$. The canonical transient receptor potential channels (TRPCs), a family of nonselective cation channels mainly used by $\mathrm{Ca}^{2+}$, can be involved in calcium influx and downstream pathways, regulating cell survival, proliferation and carcinogenesis via intracellular translocation induced by hormones and growth factors [17-19]. TRPCs are ubiquitously distributed in the body and play essential roles in human physiology and pathophysiology. TRPC3 protein levels are markedly increased in human ovarian cancer specimens compared to normal ovarian tissue specimens, and decreasing the expression of TRPC3 reduces the proliferation of cultured human ovarian cancer cells [20].

Here, we aimed to identify the expression of TRPC3 in EOC tissue samples and ES2, SKOV3, OVCAR, and HEY cells treated with E2 to determine the roles of TRPC3 in the E2-mediated regulation of EOC-related cell proliferation using TRPC3-specific siRNA interference. In addition, we compared the expression of TRPC3 genes in human ovarian cancer tissue samples from patients with that in normal ovarian tissue samples.

\section{Materials and methods}

\section{Human tissue samples}

Normal ovarian tissue comes from 6 patients with benign uterine lesions and normal ovaries who has had a hysterectomy and has had the ovarian tissue removed. Seven ovarian cancer patient tissue samples were obtained from the gynecology and obstetrics department of Xijing Hospital (Xi'an, China). Prior to the experiment, all patients were informed of the purpose of the study as well as the procedures and voluntarily agreed to provide tissue. Written consent was obtained from all participants, and all protocols were approved by the Ethics Committee of Xijing Hospital, which is affiliated with the Air Force Medical University.

\section{Cell culture}

ES2 and SKOV3 cells were cultivated in McCoy's 5A medium (HyClone/high glucose, GE Healthcare life sciences, Logan, Utah), and OVCAR and HEY cells were cultured in 1640 medium supplemented with $10 \%$ fetal calf serum (FBS; BI) and $2 \mathrm{mM} \mathrm{L}$-glutamine at $37^{\circ} \mathrm{C}$ and
5\% $\mathrm{CO}_{2}$. All cells were purchased from GENE (Shanghai, China). E2 was purchased from Sigma-Aldrich (St. Louis, Missouri,USA). E2 was dissolved into DMSO. FBS was treated with activated carbon when added during E2 stimulation, and the medium used was phenol-free red medium. Cells were treated with $10 \mathrm{nM}, 100 \mathrm{nM}$ or $1 \mu \mathrm{M}$ E2 for $24 \mathrm{~h}, 48 \mathrm{~h}$ or $72 \mathrm{~h}$. DMSO was used as a negative control.

\section{Cell vitality assay}

In total, $5 \times 10^{3}$ cells were grown in a 96-well plate with or without different concentrations of E2 $(10 \mathrm{nM}, 100 \mathrm{nM}$, and $1 \mu \mathrm{M})$. DMSO was used as a negative control. After incubation for $24 \mathrm{~h}, 48 \mathrm{~h}$ or $72 \mathrm{~h}, 20 \mu \mathrm{L}$ of $5 \mathrm{mg} / \mathrm{ml} \mathrm{3-}(4,5)$ dimethylthiahiazo-3, 5-di-phenytetrazoliumromide (MTT) was added to each well. The cells were incubated for $4 \mathrm{~h}$ at $37^{\circ} \mathrm{C}$, and then the culture medium was replaced with $150 \mu \mathrm{L}$ of DMSO (Sigma). The absorbance of the formazan product at $490 \mathrm{~nm}$ was measured with a plate reader. All experiments were performed with three replicates.

\section{Transwell migration assay}

SKOV3 cell migration was examined with chemotaxis assays. SKOV3 cells were starved for $12 \mathrm{~h}$ in McCoy's $5 \mathrm{~A}$ medium without FBS. Then, the cells were seeded $\left(2 \times 10^{4}\right.$ cells $)$ in the upper compartment of a Transwell plate (24-well plates, the poor size of Transwell is $3 \mu \mathrm{M}$ ) with $1 \mu \mathrm{M}$ E2. McCoy's 5A medium supplemented with $10 \% \mathrm{FBS}$ and $1 \mu \mathrm{M}$ E2 was added to the bottom of the well to serve as a chemoattractant for the SKOV3 cells. For the control group, an equal volume of DMSO instead of $1 \mu \mathrm{M}$ E2 was added to the medium. Next, the cells were allowed to migrate for $24 \mathrm{~h}$, after which the cells were fixed, stained with crystal violet and quantified by ImageJ software. For each biological replicate, at least three random fields were imaged. The influence of E2 on SKOV3 cells transfected with TRPC3 SiRNA was also investigated by chemotaxis assays. For this experiment, cells were allowed to migrate for $48 \mathrm{~h}$.

\section{siRNA transfection}

A TRPC3-specific siRNA and Sicon were purchased from Shanghai GenePharma Co., Ltd. The TRPC3specific siRNA and Sicon were transfected into SKOV3 cells using Lipofectamine 2000 (Invitrogen, State of California,USA). The wells without siRNA (no siRNA) or with a scrambled siRNA or a nonspecific pool of siRNAs were set as negative controls in parallel.

\section{Wound healing assay}

SKOV3 and HEY cells transfected with or without TRPC3 SiRNA were cultured on 6-well plates $\left(10^{5}\right.$ cells/ well) in McCoy's 5A medium and 1640 medium. After reaching confluency, cells were starved with serum-free 
medium for $12 \mathrm{~h}$. Then the cells monolayer was scratched horizontally with a yellow pipette tip to obtain a monolayer culture with a space without cells. Cellular debris was removed by gently washing twice with PBS and then cultured with or without $100 \mathrm{nM}$ E2. Three randomly selected fields along the scraped line were photographed using a phase contrast inverted microscope. After incubation for 12, 24, 36, 48, $72 \mathrm{~h}$, images were acquired and cell migration distances were evaluated by ImageJ.

\section{Cell counting Kit-8(CCK-8) assay}

Cell proliferation was determined by CCK-8 assay kit (MA0218-Apr-25E, Meilunbi0, China). One thousand SKOV3 and HEY cells transfected with or without TRPC3 SiRNA were cultured on 96-well plates and 100 nM E2 was added to the culture solution and cultured for $24 \mathrm{~h}$, then $10 \mu \mathrm{L}$ CCK-8 reagent was added to medium and incubated for $1 \mathrm{~h}$. OD (optical density) at $450 \mathrm{~nm}$ was read with a microplate reader. Each experiment was performed three times independently.

\section{Immunocytofluorescence analysis}

For immunocytofluorescence analysis, cells were fixed with $4 \%$ paraformaldehyde. Then, the cells were permeabilized with Triton X-100 and blocked with BSA. The cells were incubated with an anti-TRPC3 antibody (Alomone, ACC-016, Jerusalem, Israel) at $4{ }^{\circ} \mathrm{C}$ overnight and with a CY3-555-conjugated IgG antibody at $37^{\circ} \mathrm{C}$ for $2 \mathrm{~h}$ in the dark on the following day. DAPI was used for nuclear staining. Images were captured with an FSX100 microscope (Olympus, Tokyo, Japan). Tissue samples obtained from patients were fixed in $4 \%$ paraformaldehyde and serially cut into sections of $16-\mu \mathrm{m}$ thickness using a cryostat. For immunocytofluorescence, the frozen sections were subjected to antigen retrieval. An antiTRPC3 antibody was employed as the primary antibody at a dilution of 1:200; and a cyanidin-3-labeled goat anti-rabbit secondary antibody was used to visualize TRPC3 expression. All stained slides were scanned using a confocal laser scanning microscope, and images were analyzed using ImageJ software (National Institutes of Health, MD, USA).

\section{Quantitative RT-PCR for TRPC3 expression}

OVCAR, ES2, HEY and SKOV3 cells were seeded in 6well dishes. After $48 \mathrm{~h}$, the cells were treated with E2. Total RNA was extracted from the different cells using RNAiso Plus (Takara, Dalian, China) and was subsequently reverse transcribed into cDNA using PrimeScript $^{\text {ma }}$ RT.

Master Mix with random primers (Takara, Dalian, China) was used according to the manufacturer's protocol. The expression of different genes was analyzed using SYBR $^{\circ}$ PremixEx Taq ${ }^{\text {Ta }}$ II and the Bio-Rad CFX System. For real-time PCR, the reaction mixtures contained $2 \mu \mathrm{L}$ of cDNA, $0.8 \mu \mathrm{L}$ of each primer $\left(10 \mathrm{mmol}^{-1}\right), 10 \mu \mathrm{L}$ of SYBR green PCR Master Mix, and $0.2 \mu \mathrm{L}$ of ROX Reference Dye II, and distilled water was added to reach a final reaction volume of $20 \mu \mathrm{L}$. Taq DNA polymerase was activated at $95^{\circ} \mathrm{C}$ for $10 \mathrm{~min}$, followed by 40 cycles of $95^{\circ} \mathrm{C}$ for $15 \mathrm{~s}, 60^{\circ} \mathrm{C}$ for $30 \mathrm{~s}$, and $72{ }^{\circ} \mathrm{C}$ for $30 \mathrm{~s}$. Quantitative RT-PCR data were normalized to the expression of the housekeeping gene GAPDH using the $2^{-\Delta \mathrm{Ct}}$ method. The primers used in this study are shown in Table 1.

\section{Western blot analysis}

Cell lysates were extracted with a lysis buffer. Western blotting was performed with $30 \mu \mathrm{g}$ of total protein after total protein concentrations were estimated by a BCA assay, and then the protein samples were mixed with $5 \mathrm{X}$ SDS-PAGE protein loading buffer (Boster, Wuhan, P. R. China) and boiled. The samples were transferred to a PVDF membrane (Millipore, Darmstadt, Germany) by using the wet transfer method after being separated on 10\% SDS-PAGE gels (Boster, Wuhan, P. R. China). After blocking with $5 \%$ milk in TBST for $2 \mathrm{~h}$, the membranes were incubated with an anti-TRPC3 (Alomone, ACC016, Jerusalem, Israel) or anti- $\beta$-actin (CST, PA5-85271, Massachusetts, USA) antibody overnight at $4{ }^{\circ} \mathrm{C}$. To verify the specificity, the membranes were incubated with control peptide antigen and the primary antibody. $\beta$-actin was used as an internal control. The membranes were incubated with a horseradish peroxidaseconjugated anti-rabbit antibody at room temperature for $1 \mathrm{~h}$ after washing with TBST. The blots were visualized by ECL Western blotting substrate (Millipore, Darmstadt, Germany) according to the manufacturer's instructions.

\section{Measurement of intracellular $\mathrm{Ca}^{2+}$ signaling}

SKOV3 and HEY cells were grown on coverslips and loaded with the calcium indicator Fura-2 AM $(5 \mu \mathrm{M}$, Invitrogen) for $30 \mathrm{~min}$ in McCoy's 5A medium at room temperature and away from light, washed with normal calcium desklop fluid (130 mM NaCl, $5 \mathrm{mM} \mathrm{KCL}, 1.2$ $\mathrm{mM} \mathrm{MgCl} 2,1.8 \mathrm{mM} \mathrm{CaCl}_{2}, 10 \mathrm{mM}$ HEPES, $10 \mathrm{mM}$ glucose, and $\mathrm{NaOH}$ added to achieve a $\mathrm{pH}$ of 7.4) three times, continuously perfused throughout the experiment at room temperature with a nominal-calcium indicator loading buffer and challenged with ATP and E2. To investigate the effect of E2 on the expression of TRPC3 in

Table 1 Primers used in this study

\begin{tabular}{ll}
\hline Genes & Sequences (5'-3') \\
\hline GAPDH & F: ATGGGGAAGGTAAGGTCG \\
& R: GGGGTCATTGATGGCAACAATA \\
TRPC3 & F: CATTCCTGGCCATGGCTACT \\
& R: GCAGACCCAGGAAGATGATGAA \\
\hline
\end{tabular}


ovarian cancer cells, SiTRPC3 and Sicon were transfected into SKOV3 and HEY cells, which were then incubated on a glass coverslip for $48 \mathrm{~h}$. Then, $1 \mu \mathrm{M}$ E2 was added to the medium at the start of detecting intracellular $\mathrm{Ca}_{2}^{+}$. Excitation light was supplied via a Polychrome II polychromator (TILL Photomics, Oberhausen, Germany), and emission was detected by a Sensicam CCD camera (PCO Computer Optics, Kelheim, Germany). $\mathrm{Ca}^{2+}$-sensitive Fura-2 AM fluorescence was measured ratiometrically at $340 / 380-\mathrm{nm}$ wavelengths with an emission wavelength of $510 \mathrm{~nm}$. Recordings were analyzed by using Axon Imaging Workbench (Axon Instruments, Ismaning, Germany).

\section{Statistical analysis}

Each experiment was repeated at least three times, and the data are presented as the mean \pm SEM. KaplanMeier survival was analyzed by the log-rank test, and other comparisons were evaluated with one-way ANOVA. All data were graphed and analyzed statistically using GraphPad Prism 5 (GraphPad software, Inc.) and SPSS20 (IBM, Inc.). A $P$-value $<0.05$ was considered to indicate a statistically significant difference.

\section{Results}

E2 promoted the proliferation and migration of different ovarian cancer cells

To investigate the function of ER- $\alpha$ in ovarian cancer, we detected the expression of ER- $\alpha$ in different ovarian cancer cell lines. The cell line ES2 had the highest expression level among the four ovarian cancer cell lines, while the cell line OVCAR had the lowest expression level (Fig.1a). Next, we detect the cell viability of four cell lines under E2 conditions. Different cell lines were grown with or without different doses of E2. Cell viability was measured by an MTT assay. The cell viability of all cells, especially that of ES2 cells, was influenced by $1 \mu \mathrm{M}$ E2 (Fig. 1b). To further understand the influence of E2 on cell migration, in vitro Transwell assays was performed. The Transwell assays showed that SKOV3 and HEY cell migration was significantly increased under E2 conditions (Fig. 1c and d and Fig.1e and f). The cell number decreased when SKOV3 and HEY cells transferred with Si TRPC3 while E2 can increase the cell number (Fig. 2e and f). CCK8 assay and wound healing assay results shown that E2 promote the cell proliferation while silenced of TRPC3 inhibit the cell proliferation which can reverse by E2 in HEY and SKOV3 cells (Fig. 2). All results demonstrate that E2 enhances cell proliferation and migration.

Tissue samples from ovarian cancer patients showed high expression of TRPC3

To detect the expression of TRPC3 in ovarian cancer tissue samples, ovarian tissue samples from ovarian cancer and uterine fibroid patients were collected to analyze the expression of TRPC3. The ovarian tissue samples from the patients with ovarian cancer showed higher protein expression of TRPC3 (Fig. 3c) than the ovarian tissue samples from the uterine fibroid patients. Immunocytofluorescence analysis showed that the expression of TRPC3 in serous ovarian cancer tissue was higher than that in normal tissue (Fig. 3). We also used blocking peptide to examine the specificity of the band around $97 \mathrm{kDa}$. Result shown that the band around $97 \mathrm{kDa}$ specifically represent TRPC3(Fig S2).

\section{Expression levels of TRPC 3 differed among ovarian cancer cells}

To investigate whether E2 promotes the proliferation of ovarian cancer cells through TRPC3, we detected the expression of TRPC3 in different ovarian cancer cell lines through Western blot and immunocytofluorescence analyses. The expression of TRPC3 in SKOV3 and OVCAR cells was higher than that in HEY and ES2 cells (Fig. 3b and d).

\section{E2 increased the expression of TRPC3 in different ovarian cancer cells}

To further understand the molecular mechanism by which E2 promotes cell migration, we detected the expression of TRPC3 in different cells under E2 treatment conditions. E2 $(1 \mu \mathrm{M})$ induced the upregulation of TRPC3 expression at the mRNA level (Fig. 4a). E2, especially $100 \mathrm{nM} \mathrm{E2}$, also increased the expression of TRPC3 in SKOV3 and HEY cells at the protein level (Fig. 4b and c).

\section{Role of E2 in TRPC3-mediated Ca2+ uptake}

Previous studies have shown that TRPC 3 acts as a Ca2 + -permeable channel in E2-responsive cells. To test whether E2 regulates TRPC3-mediated $\mathrm{Ca} 2+$ uptake, cells induced with $1 \mu \mathrm{M}$ E2, ATP, and SiTRPC3 were analyzed using $\mathrm{Ca} 2+$ imaging. Treatment with $1 \mu \mathrm{M}$ E2 facilitated intracellular calcium influx, which was consistent with the result of for ATP treatment in different cells (Fig. 5a and c). Intracellular calcium influx was lower when both SKOV3 cells and HEY cells were transfected with SiTRPC3 than transfected with Sicon when cells were treated with $1 \mu \mathrm{M}$ E2 (Fig. $5 \mathrm{~b}$ and d). The results suggested that specifically knocking down TRPC3 expression was associated with a block in rapid calcium influx. All results indicate that E2 influences intracellular calcium influx by influencing the expression of TRPC3.

\section{Discussion}

EOC is the most lethal gynecological cancer and represents the seventh most commonly diagnosed cancer among women worldwide [21]. Approximately $75 \%$ of 


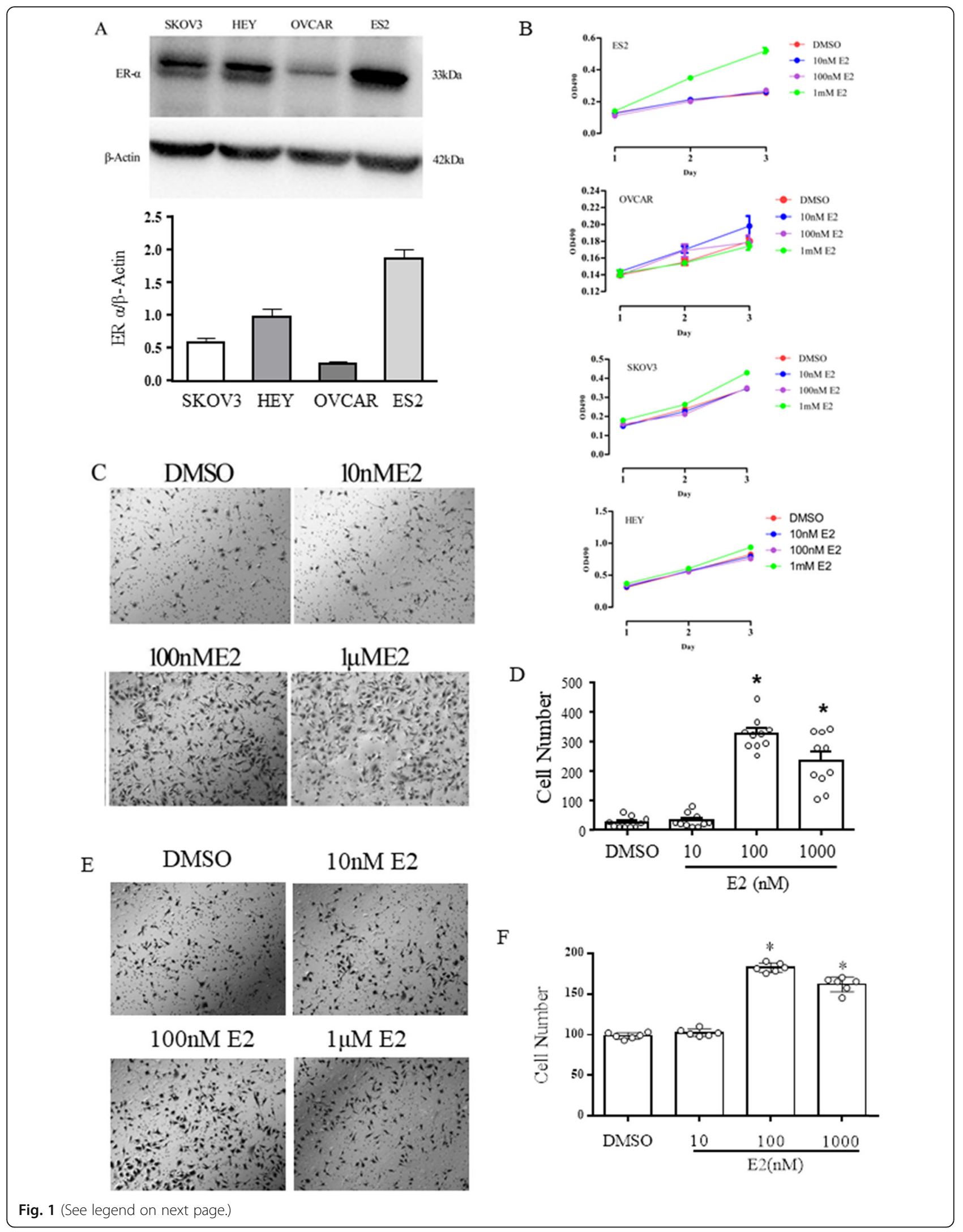


(See figure on previous page.)

Fig. 1 E2 increased proliferation and migration in ovarian cancer cells. a The expression levels of ER-a in ovarian cancer cells (SKOV3, HEY and ES2 cells) were detected by Western blot analysis. $\beta$-Actin was used as a loading control. b The ovarian cancer cell lines ES2, OVCAR, SKOV3, and HEY were treated with $10 \mathrm{nM}, 100 \mathrm{nM}$ or $1 \mu \mathrm{M}$ E2 for different times ( $24 \mathrm{~h}, 48 \mathrm{~h}$ or $72 \mathrm{~h}$ ). Cell growth was detected by an MTT assay (OD490 nm). The ovarian cancer cell line SKOV3((c) and (d)) and HEY ((e) and (f))was treated with $10 \mathrm{nM}, 100 \mathrm{nM}$ or $1 \mu \mathrm{M}$ E2 for $48 \mathrm{~h}$. DMSO was used as a negative control. Cell migration was analyzed by a Transwell migration assay. The experiment was repeated three times

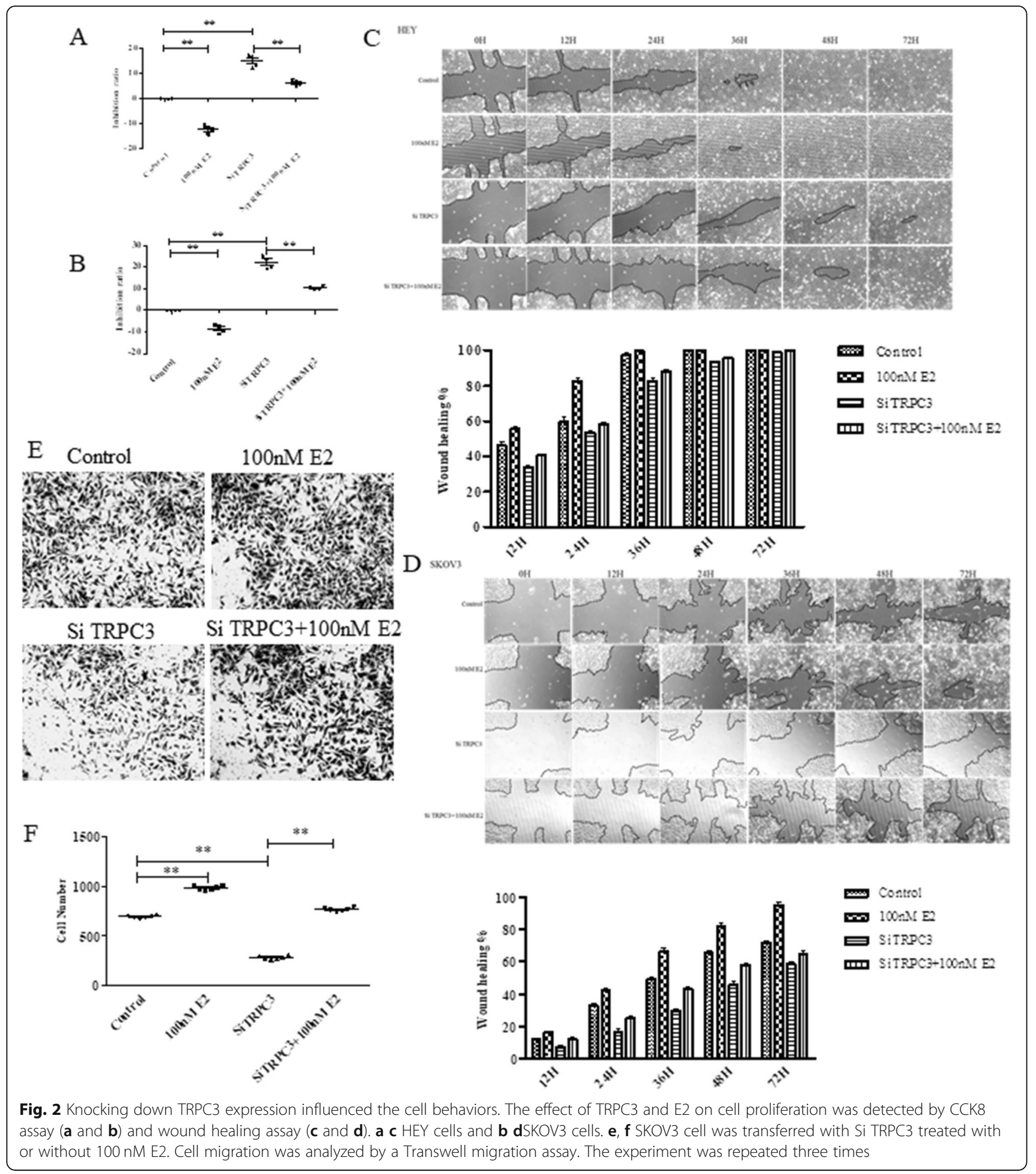




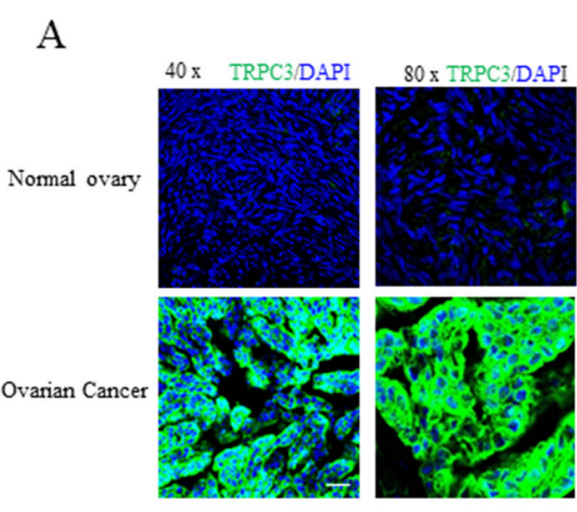

B

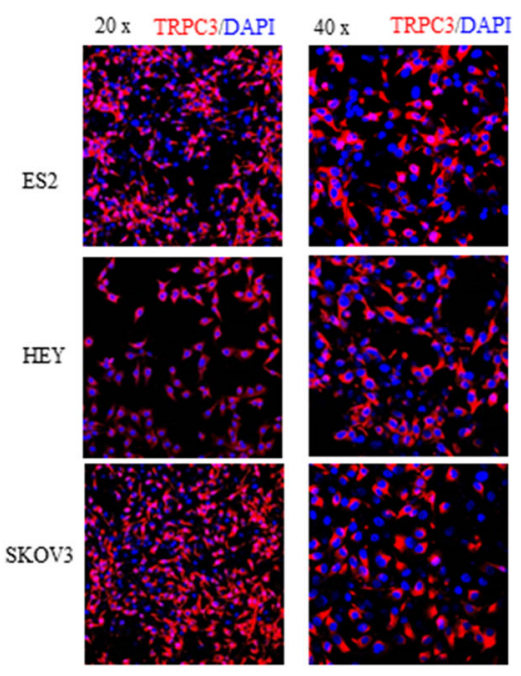

$\mathrm{C}$

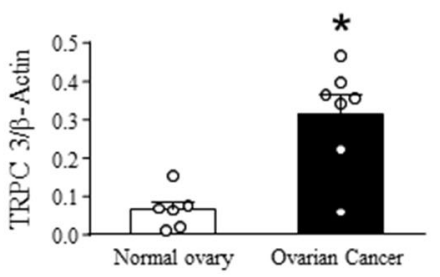

$\mathrm{D}$
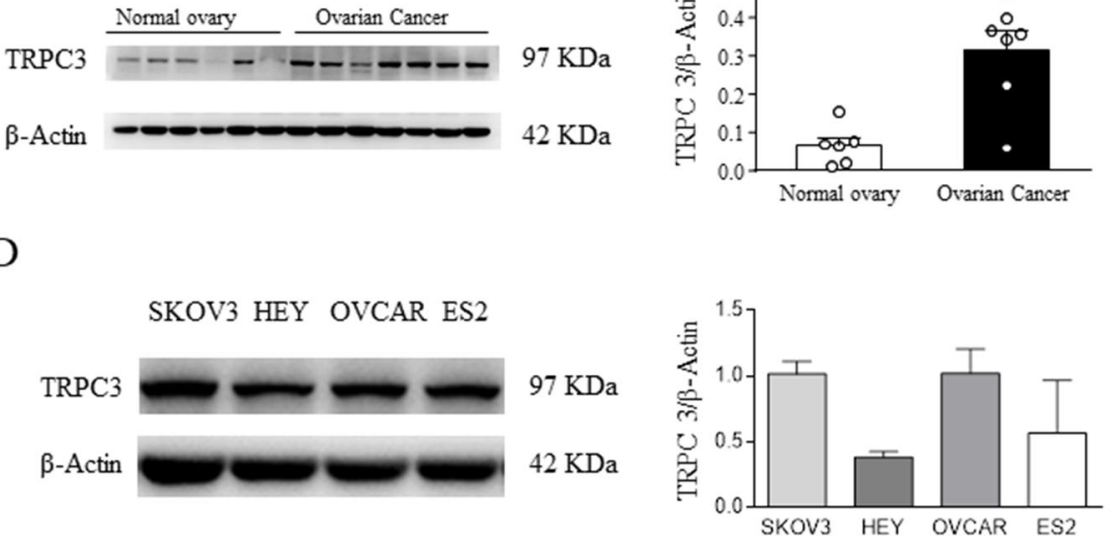

Fig. 3 TRPC3 expression in ovarian cancer cells and tissues. a The expression levels of TRPC3 in ovarian cancer tissue samples and ovarian tissue samples from patients with benign uterine lesions and normal ovaries who has had a hysterectomy and has had the ovarian tissue removed detected using immunofluorescence. $\mathbf{b}$ The expression levels of TRPC3 in ovarian cancer cells (SKOV3, HEY and ES2 cells) were detected using immunofluorescence. The TRPC3 protein was immunofluorescently labeled and imaged using confocal microscopy. DAPI was used as a nuclear staining marker. c The expression levels of TRPC3 in ovarian cancer tissue samples and ovarian tissue samples from benign lesion patients detected using Western blot analysis. $\mathbf{d}$ Western blot analysis was used to detect TRPC3 expression in four ovarian cancer cell lines. $\beta$-Actin was used as a loading control

patients are diagnosed at an advanced stage because of the asymptomatic nature of EOC. Thus, it is urgent to understand the pathogenesis of EOC. E2 exhibits a broad spectrum of physiological functions ranging from regulation of the menstrual cycle and reproduction to modulation of bone density, brain function, and cholesterol mobilization $[11,12]$. Notwithstanding the beneficial actions of endogenous E2, sustained exposure to exogenous E2 is an established risk factor for various cancers, especially those of the breast and endometrium [22]. It has been reported that an elevated E2 level is a risk factor for ovarian cancer, but the associated molecular mechanism is not clear. In the present work, we used
E2 to stimulate different ovarian cancer cell lines to investigate the role of $\mathrm{E} 2$ in ovarian cancer.

To improve the treatment of EOC, disease pathogenesis is still being explored. Numerous studies have demonstrated the associations of E2 with the development and/or progression of various types of cancer, including cancers of the ovaries, lungs, and colon $[13,23]$. Previous work revealed E2 as a risk factor for EOC [24, 25]. In the present study, we found that E2 increased the cell viability of different ovarian cancer cells, especially SKOV3 cells, and that it improved SKOV3 cell migration and proliferation in vitro (Figs. 1 and 3). The positive effects of E2 on the migration and proliferation of ovarian 
A
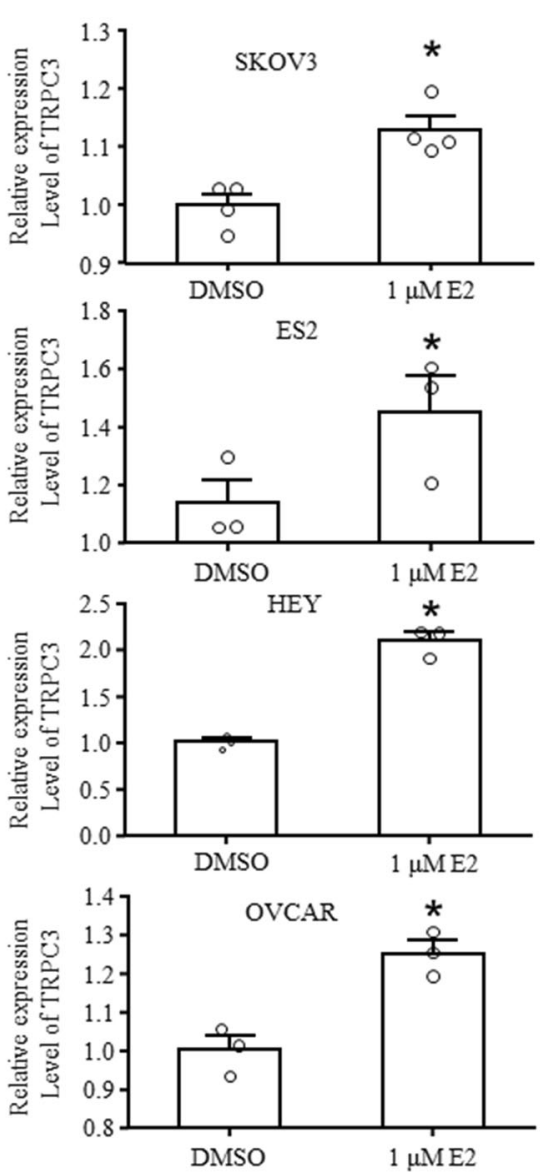

B

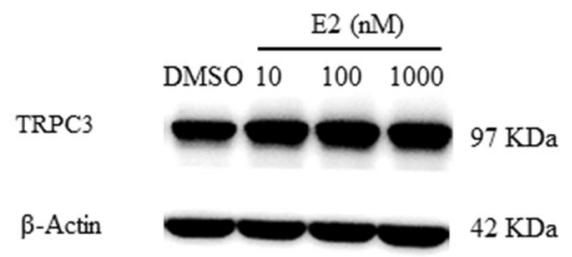

C

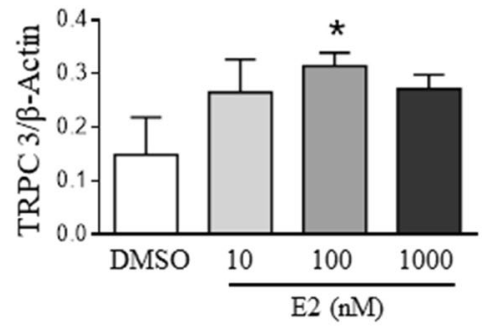

DMSO $1 \mu \mathrm{ME} 2$

TRPC3

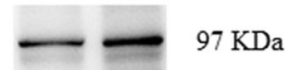

$\beta$-Actin

$42 \mathrm{KDa}$

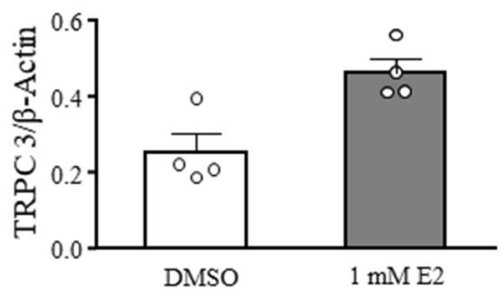

Fig. 4 E2 increased the expression of TRPC3 in ovarian cancer cells. a The ovarian cancer cell lines SKOV3, ES2, HEY, and OVCAR were treated with $1 \mu \mathrm{M}$ E2 for $48 \mathrm{~h}$. The expression level of TRPC3 was detected by qRT-PCR. The experiment was repeated three times. The ovarian cancer cell line SKOV3 (b) was treated with $10 \mathrm{nM}, 100 \mathrm{nM}$ or $1 \mu \mathrm{M}$ E2 for $48 \mathrm{~h}$ and HEY (c) treated with $1 \mu \mathrm{M}$ E2 for $48 \mathrm{~h}$. Western blot analysis was used to detect TRPC3 expression. $\beta$-Actin was used as a loading control

cancer cells suggest that E2 plays significant roles in the proliferation and migration of ovarian cancer. We also found that the expression of ER- $\alpha$ in different ovarian cancer cells was distinct. Taken together, these results demonstrate that the effect of E2 on EOC is mainly due to the role of EOC in promoting cancer cell migration and proliferation. However, the molecular mechanism by which E2 promotes cancer cell migration and proliferation is not clear.

$\mathrm{Ca}^{+}$signaling is believed to play a central role in the signaling cascades involved in tumorigenesis and neoplastic progression [26]. Inhibitors of $\mathrm{Ca}_{2}^{+}$-dependent signaling suppress the proliferation of cancer cells in vitro and solid tumors in vivo [27, 28]. The canonical TRPCs are a subfamily that has been proposed to comprise protein tyrosine kinase- or $\mathrm{G}$ protein-coupled receptor-operated $\mathrm{Ca}^{+}$channels (ROCs) or internal $\mathrm{Ca}^{+}$store-operated channels (SOCs), which mediate the $\mathrm{Ca} 2^{+}$signaling pathway activated by many hormones and growth factors $[15,29]$. TRPCs are ubiquitously distributed in the body and play essential roles in human physiology and pathophysiology. Several studies have demonstrated the expression of TRPCs in different types of cancer cells or cancer tissues [30-32]. Previous studies have shown that TRPC3 protein levels are significantly increased in human ovarian cancer specimens compared to normal ovarian tissue samples [20]. Consistent with this observation, in the present study, we found that TRPC3 expression was markedly increased in human ovarian cancer samples (Fig. 2). Our results and those of previous studies suggest that TRPC3 plays an important role in ovarian cancer. In this study, we found that the expression of TRPC3 increased after E2 stimulation. Intracellular calcium influx was lower when SKOV3 cells were transfected with SiTRPC3 than when SKOV3 cells were treated with $1 \mu \mathrm{M}$ E2. These results indicated that E2 promotes the proliferation of ovarian cancer cells by upregulating the expression of TRPC3. 


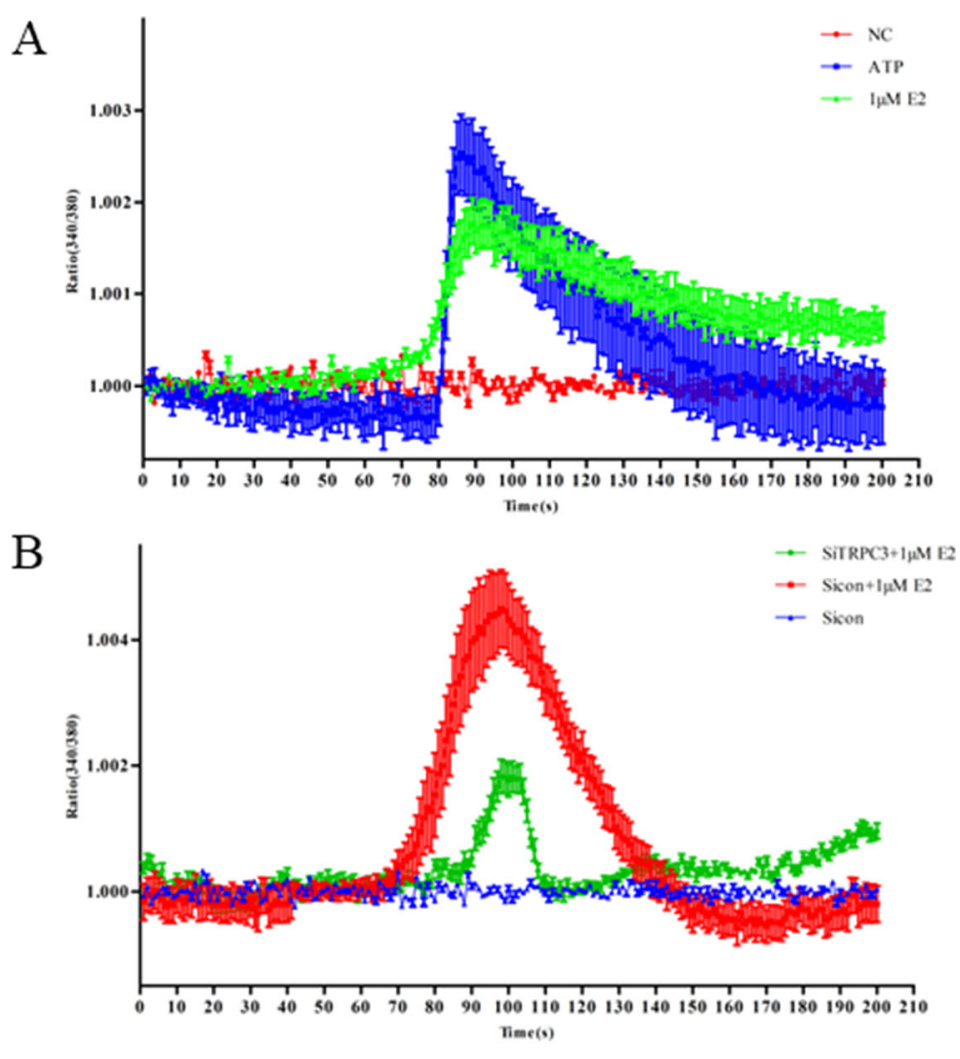

C

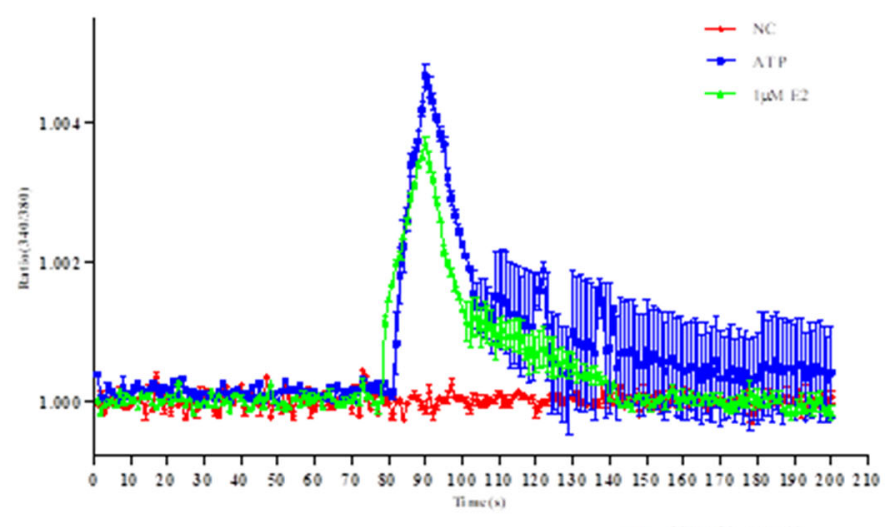

$\mathrm{D}$

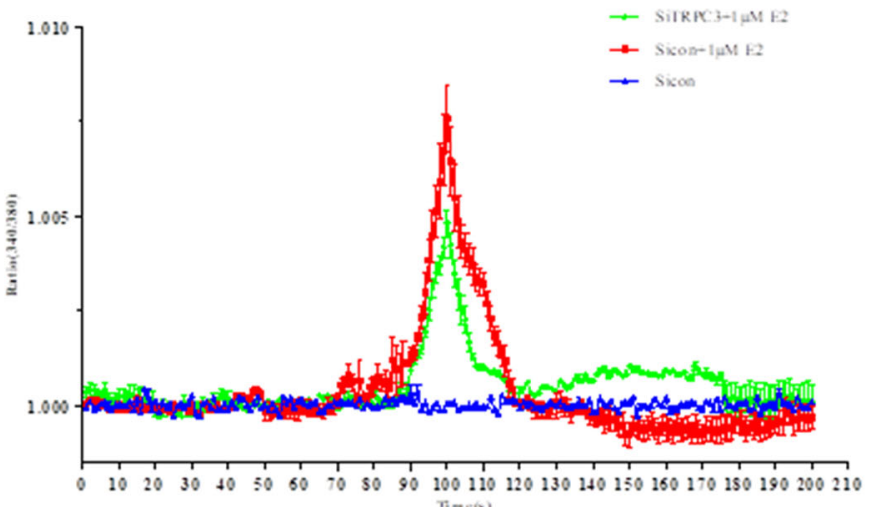

Fig. 5 (See legend on next page.) 
(See figure on previous page.)

Fig. 5 Knocking down TRPC3 expression blocked E2-associated effects on calcium influx. The effect of E2 on calcium influx is shown in (a, SKOV3 cells) and (c, HEY cells). ATP treatment was used as a positive control. A representative image of intracellular calcium influx ([Ca2 $\left.{ }^{+}\right]$) is shown. The EOC cell line SKOV3 was used to analyze the effect of downregulating TRPC3 expression on [Ca2 $\left.{ }^{+}\right]_{1}(\mathbf{b}$, SKOV3 cells) and (d, HEY cells). SiTRPC3 and Sicon were transfected into SKOV 3 and HEY cells, which were then incubated on glass coverslips for $48 \mathrm{~h}$. Then, $1 \mu \mathrm{M}$ E2 was added to the medium at the start of detecting intracellular $\mathrm{Ca} 2+$., and then stained with the fluorescent dye Fluo- $2 \mathrm{AM}$ before observation. $\left[\mathrm{Ca}_{2}{ }^{+}\right]_{\mathrm{i}}$ was determined using the F340/380 ratio. The experiment was repeated three times

Because of the possibility of TRPC heteromultimerization, biological activities may involve more than one TRPC, which makes it challenging to identify the function of a single subtype [33]. Interestingly, we found that TRPC3 was involved in E2 regulation. Future work will address whether E2 influences other members of the TRPC family and the interrelations among the subtypes.

In summary, the results presented in this study demonstrated that the molecular mechanism of E2 involved promoting the proliferation of ovarian cancer cells. We demonstrated that E2 stimulated proliferation and migration by upregulating the expression of TRPC3, which enhanced intracellular calcium influx.

Additional future experiments might include overexpressing TRPC3 to observe the effects and experiments exploring the molecular mechanism by which estrogen regulates TRPC3 expression.

\section{Supplementary information}

Supplementary information accompanies this paper at https://doi.org/10. 1186/s13048-020-00621-y.

Additional file 1: Figure S1. Specific verification of TRPC3 used control peptide antigen. Control peptide antigen was used to demonstrate specificity of the band around $97 \mathrm{kDa}$. It showed that band around 97 kDa specifically represent TRPC3.

\section{Acknowledgements}

The authors acknowledge Dr. Hong Fan (Air Force Medical University) for his assistance for his advice on data and statistical analysis and providing language help and poof reading the article.

\section{Authors' contributions}

R.X. and B.C. designed and supervised the study. S.L. and K.J. performed the experiments and wrote the manuscript. Y.Z. performed the complement experiment. S.H., J.L., X.H. and W.C. conducted the sample collection. X.H., W.C. and C. L conducted physiological data analysis. C.L., R.X.and B.C. analysed the data and edited the manuscript. All authors read and approved the final manuscript.

\section{Funding}

This work was supported by the National Natural Scientific Foundation of China (No. 81672583, No.81702668, No.81402133, No.81870867).

\section{Availability of data and materials}

The datasets used and/or analysed during the current study are available from the corresponding author on reasonable request.

\section{Ethics approval and consent to participate}

All patients were informed of the purpose of the study as well as the procedures and voluntarily agreed to provide tissue. Written consent was obtained from all participants, and all protocols were approved by the Ethics
Committee of Xijing Hospital, which is affiliated with the Air Force Medical University.

\section{Consent for publication}

Not applicable.

\section{Competing interests}

The authors declare that this research was conducted without any commercial or financial relationships and that no conflict of interest exists.

\section{Author details}

${ }^{1}$ Department of Gynecology and Obstetrics, Xijing Hospital, Air Force Medical University, Xi'an 710032, Shannxi, China. ${ }^{2}$ Department of Spine Surgery, Honghui Hospital, Xi'an Jiaotong University College of Medicine, Xi'an 710054, Shaanxi, China. ${ }^{3}$ Department of neurobiology, Air Force Medical University, Xi'an 710032, Shannxi, China.

Received: 27 August 2019 Accepted: 6 February 2020

Published online: 22 February 2020

\section{References}

1. Ferlay J, Soerjomataram I, Dikshit R, Eser S, Mathers C, Rebelo M, Parkin DM, Forman D, Bray F. Cancer incidence and mortality worldwide: sources, methods and major patterns in GLOBOCAN 2012. Int J Cancer. 2015;136: E359-86. https://doi.org/10.1002/ijc.29210.

2. Doherty JA, Peres LC, Wang C, Way GP, Greene CS, Schildkraut JM. Challenges and opportunities in studying the epidemiology of ovarian Cancer subtypes. Curr Epidemiol Rep. 2017;4:211-20. https://doi.org/10. 1007/s40471-017-0115-y.

3. Vergote IB, Van Nieuwenhuysen E, Vanderstichele A. How to Select Neoadjuvant Chemotherapy or Primary Debulking Surgery in Patients With Stage IIIC or IV Ovarian Carcinoma. J Clin Oncol. 2016;34:3827. https://doi. org/10.1200/Jco.2016.69.7458.

4. A. Karam, J.A. Ledermann, J.W. Kim, J. Sehouli, K. Lu, C. Gourley, N. Katsumata, R.A. Burger, B.H. Nam, M. Bacon, C. Ng, J. Pfisterer, R.L.M. Bekkers, A. Casado Herraez, A. Redondo, H. Fujiwara, N. Gleeson, O. Rosengarten, G. Scambia, J. Zhu, A. Okamoto, G. Stuart, K. Ochiai, C. participants of the 5th Ovarian Cancer Consensus, Fifth Ovarian Cancer Consensus Conference of the Gynecologic Cancer InterGroup: first-line interventions, Ann Oncol 28 (2017) 711-717. doi: https://doi.org/10.1093/annonc/mdx011.

5. Lheureux S, Gourley C, Vergote I, Oza AM. Epithelial ovarian cancer. Lancet. 2019:393:1240-53. https://doi.org/10.1016/S0140-6736(18)32552-2.

6. Franceschi S, La Vecchia C, Booth M, Tzonou A, Negri E, Parazzini F, Trichopoulos D, Beral V. Pooled analysis of 3 European case-control studies of ovarian cancer: II. Age at menarche and at menopause, International journal of cancer. Int J Can. 1991;49:57-60.

7. Vanderhyden BC. Loss of ovarian function and the risk of ovarian cancer Cell Tissue Res. 2005;322:117-24. https://doi.org/10.1007/s00441-005-1100-1.

8. Choi JH, Wong AS, Huang HF, Leung PC. Gonadotropins and ovarian cancer. Endocr Rev. 2007;28:440-61. https://doi.org/10.1210/er.2006-0036.

9. Lau KM, Mok SC, Ho SM. Expression of human estrogen receptor-alpha and -beta, progesterone receptor, and androgen receptor mRNA in normal and malignant ovarian epithelial cells. Proc Natl Acad Sci U S A. 1999;96:5722-7. https://doi.org/10.1073/pnas.96.10.5722

10. Lindgren PR, Cajander S, Backstrom T, Gustafsson JA, Makela S, Olofsson JI. Estrogen and progesterone receptors in ovarian epithelial tumors. Mol Cell Endocrinol. 2004;221:97-104. https://doi.org/10.1016/j.mce.2004.02.020.

11. Koos RD. Minireview: putting physiology back into estrogens' mechanism of action. Endocrinology. 2011;152:4481-8. https://doi.org/10.1210/en.2011-1449. 
12. Shang Y. Molecular mechanisms of oestrogen and SERMs in endometrial carcinogenesis. Nat Rev Cancer. 2006:6:360-8. https://doi.org/10.1038/ nrc1879.

13. Shang Y. Hormones and cancer. Cell Res. 2007;17:277-9. https://doi.org/10 1038/cr.2007.26

14. O'Donnell AJ, Macleod KG, Burns DJ, Smyth JF, Langdon SP. Estrogen receptor-alpha mediates gene expression changes and growth response in ovarian cancer cells exposed to estrogen. Endocr Relat Cancer. 2005;12:85166. https://doi.org/10.1677/erc.1.01039.

15. Clapham DE. TRP channels as cellular sensors. Nature. 2003;426:517-24. https://doi.org/10.1038/nature02196.

16. Xu SZ, Sukumar P, Zeng F, Li J, Jairaman A, English A, Naylor J, Ciurtin C, Majeed Y, Milligan CJ, Bahnasi YM, Al-Shawaf E, Porter KE, Jiang LH, Emery P, Sivaprasadarao A, Beech DJ. TRPC channel activation by extracellular thioredoxin. Nature. 2008:451:69-72. https://doi.org/10.1038/nature06414.

17. Goel M, Zuo CD, Schilling WP. Role of CAMP/PKA signaling cascade in vasopressin-induced trafficking of TRPC3 channels in principal cells of the collecting duct. Am J Physiol Renal Physiol. 2010;298:F988-96. https://doi. org/10.1152/ajprenal.00586.2009.

18. Smyth JT, Lemonnier L, Vazquez G, Bird GS, Putney JW Jr. Dissociation of regulated trafficking of TRPC3 channels to the plasma membrane from their activation by phospholipase C. J Biol Chem. 2006;281:11712-20. https://doi. org/10.1074/jbc. M510541200.

19. Kanzaki M, Zhang YQ, Mashima H, Li L, Shibata H, Kojima I. Translocation of a calcium-permeable cation channel induced by insulin-like growth factor-l. Nat Cell Biol. 1999;1:165-70. https://doi.org/10.1038/11086.

20. Yang SL, Cao Q, Zhou KC, Feng YJ, Wang YZ. Transient receptor potential channel C3 contributes to the progression of human ovarian cancer. Oncogene. 2009;28:1320-8. https://doi.org/10.1038/onc.2008.475.

21. Jayson GC, Kohn EC, Kitchener HC, Ledermann JA. Ovarian cancer. Lancet. 2014;384:1376-88. https://doi.org/10.1016/S0140-6736(13)62146-7.

22. Prentice RL, Anderson GL. The women's health initiative: lessons learned. Annu Rev Public Health. 2008;29:131-50. https://doi.org/10.1146/annurev. publhealth.29.020907.090947.

23. Folkerd EJ, Dowsett M. Influence of sex hormones on cancer progression. J Clin Oncol. 2010;28:4038-44. https://doi.org/10.1200/JCO.2009.27.4290.

24. Deligeoroglou E, Michailidis E, Creatsas G. Oral contraceptives and reproductive system cancer. Ann N Y Acad Sci. 2003;997:199-208. https:// doi.org/10.1196/annals.1290.023.

25. Ness RB, Grisso JA, Klapper J, Schlesselman JJ, Silberzweig S, Vergona R, Morgan $\mathrm{M}$, Wheeler JE. Risk of ovarian cancer in relation to estrogen and progestin dose and use characteristics of oral contraceptives. SHARE study group. Steroid hormones and reproductions. Am J Epidemiol. 2000;152:23341. https://doi.org/10.1093/aje/152.3.233.

26. Monteith GR, McAndrew D, Faddy HM, Roberts-Thomson SJ. Calcium and cancer: targeting Ca2+ transport. Nat Rev Cancer. 2007;7:519-30. https://doi. org/10.1038/nrc2171.

27. Tao X, Zhao N, Jin H, Zhang Z, Liu Y, Wu J, Bast RC Jr, Yu Y, Feng Y. FSH enhances the proliferation of ovarian cancer cells by activating transient receptor potential channel C3. Endocr Relat Cancer. 2013;20:415-29. https:// doi.org/10.1530/ERC-12-0005.

28. Murph MM, Liu W, Yu S, Lu Y, Hall H, Hennessy BT, Lahad J, Schaner M, Helland A, Kristensen G, Borresen-Dale AL, Mills GB. Lysophosphatidic acidinduced transcriptional profile represents serous epithelial ovarian carcinoma and worsened prognosis. PLoS One. 2009;4:e5583. https://doi. org/10.1371/journal.pone.0005583.

29. Zeng B, Yuan C, Yang X, Atkin SL, Xu SZ. TRPC channels and their splice variants are essential for promoting human ovarian cancer cell proliferation and tumorigenesis. Curr Cancer Drug Targets. 2013;13:103-16.

30. Beck B, Lehen'kyi V, Roudbaraki M, Flourakis M, Charveron M, Bordat P, Polakowska R, Prevarskaya N, Skryma R. TRPC channels determine human keratinocyte differentiation: new insight into basal cell carcinoma. Cell Calcium. 2008;43:492-505. https://doi.org/10.1016/j.ceca.2007.08.005

31. El Boustany C, Bidaux G, Enfissi A, Delcourt P, Prevarskaya N, Capiod T. Capacitative calcium entry and transient receptor potential canonical 6 expression control human hepatoma cell proliferation. Hepatology. 2008;47: 2068-77. https://doi.org/10.1002/hep.22263.

32. Aydar E, Yeo S, Djamgoz M, Palmer C. Abnormal expression, localization and interaction of canonical transient receptor potential ion channels in human breast cancer cell lines and tissues: a potential target for breast cancer diagnosis and therapy. Cancer Cell Int. 2009;9:23. https://doi.org/10.1186/ 1475-2867-9-23.

33. Flockerzi V. An introduction on TRP channels. Handb Exp Pharmacol. 2007: 1-19. https://doi.org/10.1007/978-3-540-34891-7_1.

\section{Publisher's Note}

Springer Nature remains neutral with regard to jurisdictional claims in published maps and institutional affiliations.
Ready to submit your research? Choose BMC and benefit from:

- fast, convenient online submission

- thorough peer review by experienced researchers in your field

- rapid publication on acceptance

- support for research data, including large and complex data types

- gold Open Access which fosters wider collaboration and increased citations

- maximum visibility for your research: over $100 \mathrm{M}$ website views per year

At BMC, research is always in progress.

Learn more biomedcentral.com/submissions 